\title{
THE NUMBER OF MOULTS IN INSECTS OF DIFFERENT ORDERS.*
}

BY A. S. PACKARD, PROVIDENCE, R. I.

It will be seen from the data here presented that the number of moults is as a rule greatest in metabolic insects with the longest lives, and that an excessive number of ecdyses is due to some physical cause, such as lack of food combined with low temperature.

In Campodea there is a single fragmentary moult (Grassi), while the Collembola (Macrotoma plumbea) shed their skin throughout life. (Sommer.)

In the winged insects, especially Lepidoptera, the number of moults is dependent on climate. Insects of wide distribution growing faster in warmer climates consequently shed their skins oftener; for example the same species may moult once oftener in the southern than in the northern States, as in the case of Callosamia promethea, which in West Virginia is double-brooded. Hibernating larvae moult once oftener than those of the summer brood (Edwards). Weniger by rearing the larvae of Antheraea mylitta and Eacles imperialis, and which when reared under normal conditions actually have the six stages, when reared in a warm moist atmosphere of about $25^{\circ} \mathrm{C}$. have but five stages, $i . e$, moult but four times. In the hot and moist climate of Ceylon,

* Published in advance from the author's Text book of Entomology. Any corrections or additions would be thankfully received by the author.
A. mylitta has but five stages. (Psyche V, p. 28.)

Acrydians moult five times; Diapheromera femorata but twice (Riley); a katydid (Microcentrum retinervis) moults four times (Comstock). Mantis religiosa, according to Pagenstecher moults seven times, having eight stages, including that of the singular prenymph. Cockroaches (Periplaneta americana) are said by Marlatt to pass through a variable number of moults, there being sometimes as many as seven stages.

In the Homoptera there are in general from two to four moults; thus in Typhlocyba there are five stages, in Psocus four, and in Aphis at least three, and in Psylla four during the nymphal state. Riley states that the nymph of the female Coccid, Icerya purchasi, sheds its skin three times and the male twice. Notwithstanding its slow growth, Riley says, the 17 -year Cicada moults oftener than once a year, and the number of larval stages probably amounts to twenty-five or thirty in all. The bedbug sheds its skin five times; and with the last moult appear the minute wingpads characteristic of the adult. In Conorhinus sanguisuga there are "at least two larval stages and pupal stages" (Marlatt).

In the May-fly, Chloëon, the num- 
ber of ecdyses is twenty. The Neuropterous Ascalaphus (Helecomitus) insimulans of Ceylon moults three times before pupating. Among the Mecoptera Felt has shown that Panorpa rufescens moults seven times.

In Coleoptera the normal or usual number is not definitely known; Meloë moults five times; Phytonomus punctatus, the clover leaf weevil, moults three times, according to Riley, who has observed that Dermestes vulpinus passes through seven larval stages.

In the breeding jars, with plenty of food and a constant temperature of from $68^{\circ}$ to $78^{\circ} \mathrm{F}$., the larvae cast their first skin in from four to nine days, the great majority moulting at seven days. Under the same conditions the second skin was castat from fourto seven days, the majority moulting at six days; the third skin at from three to six days, the majority moulting at five days; and the fourth skin at from three to six days, the majority moulting at five days; the fifth skin at from five to seven days, and the sixth skin at six days. There are thus seven larval stages. (Report for 1885, p. 26o.)

Riley has ascertained that by rearing isolated larvae of Tenebrio molitor, one after being kept nearly a year had moulted eleven times, when it died. A second larva hatched June 5 , had moulted twelve times by June ioth of the following year ( 1877 ), when it also died. Of T. obscurus three larvae were reared to the imago state. One moulted eleven times by August 3oth of the same year, pupated Jan. 2oth, 1877 , and finally became a beetle Feb. 7, 1877. The other two both moulted twelve times and reached the imago state $\mathrm{Feb}$. I8 and March 9th respectively. "All were, as nearly as possible, under like conditions of food and surroundings, and in all cases the moult that gave the pupa is not considered among the larval moults."
Two larvae of the museum pest (Trogoderma tarsale) were kept by Riley in a tight tin box with an old silkworm cocoon. "They were half grown when placed in the box. On November 8th, I880, there were in the box twenty-eight larva skins, all very much of a size, the larva having apparently grown but little. The skins were removed and the box closed again as tightly as possible. Recently, or after a lapse of two years, the box was again opened and we found one of the larvae dead and shrivelled up; but the other was living and apparently not changed in appearance. There were fifteen larva skins in the box. We cannot tell when the one larva died, but it is certain that within a little more than three and a half years, two larvae shed not less than fortythree skins, and that one larva did not, during that time, appreciably increase in size. "We know of no observations which indicate the normal or average length of life, or number of moults in either Tenebrio or Trogoderma, but it is safe to assume from what is known, in these respects, of allied species, that in both the instances here referred to, but particularly in the case of Trogoderma, development was retarded by insufficient nutrition and that the frequent moulting and slow growth resulted therefrom and were correlated." * Further observations such as these are greatly needed.

Of the Siphonaptera the common cat and dog flea (Pulex serraticeps) moults three times before pupating (Howard).

In Lepidoptera the usual or average number of moults is four, but the number varies considerably, the greatest number yet known occurring in Phyrrarctia isabella which, Dr. Dyar informs me, moults ten times.

From Dyar's observations it appears that there are usually five larval stages,

\footnotetext{
* American Naturalist, xvii. May r883. pages $547-548$.
} 
but six and seven stages are not infrequent, while there are eight in Scepsis and Apatelodes and nine and ten in Arctians, while the European Nola centonalis moults nine times, other species shedding their skins six times (Buckler): (Psyche, v, pages 420-422). Callosamia promethea moults but three times as a rule. Orgyia antiqua was found by Hellins to moult from three to five times. Riley found that in O. leucostigma the males moult four times, the female four but sometimes five times, while Dyar states that in O. gulosa the male larvae moult three or four times, the female always four times; while in $O$. antiqua there are six stages, and in the female seven. Lithocolletis, Chambers thinks, as a rule moults eight times, Comstock thinks L. hamadryadellu casts its skin seven or eight times.

In the blow-fly (Calliphora) Leuckart and Weismann have inferred at least two moults, while Weismann suspects that there are as many as four. In Musca domestica we have observed that the larva moults three times; in Oestridae there are three larval stadia (Brauer). In Corethra there are four larval moults, and Miall thinks there are probably as many. In the phytophagous Hymenoptera there are three moults or four larval stages in Nematus erichsonii, but Dyar informs me that less than four stages in saw-fly larvae is very rare, that he has only one record of less than five, and that that is doubtful; five for Nematid, six and seven for others, is certainly the rule. "The highest I have is the indication of eleven stages for Harpiphorus varianus" (Can. Ent., xxvii, p. 208). In Bombus we have observed five different sizes of larvae and hence suppose the least number of ecdyses is five, while we are disposed to believe that this insect as well as wasps and bees in general shed their skins as many as ten times during their entire existence.

The honey bee, Cheshire thinks, since he has found the red and ruptured pellicles, probably moults six times before it spins its cocoon, or passes into the semipupa condition. (Bees and BeeKeeping, p. 20).

As to the cause of the great number of moults in the Arctians and the beetles experimented with by Riley, it would seem that cold and the lack of food during hibernation were the agents in Arctians, and starvation or the lack of food in the case of the beetles, such cause preventing growth, though the hypodermis-cells retained their activity.

\section{DIPTERA OF THE ORGAN MOUNTAINS IN SOUTHERN NEW MEXICO. - I.}

BY C. H. TYLER TOWNSEND, LAS CRUCES, NEW MEXICO.

In Science, for Dec. 8, 1893, the writer gave a general description of the
Organ Mountain range, which lies in the Doña Ana county, some fifteen miles 



Submit your manuscripts at

http://www.hindawi.com
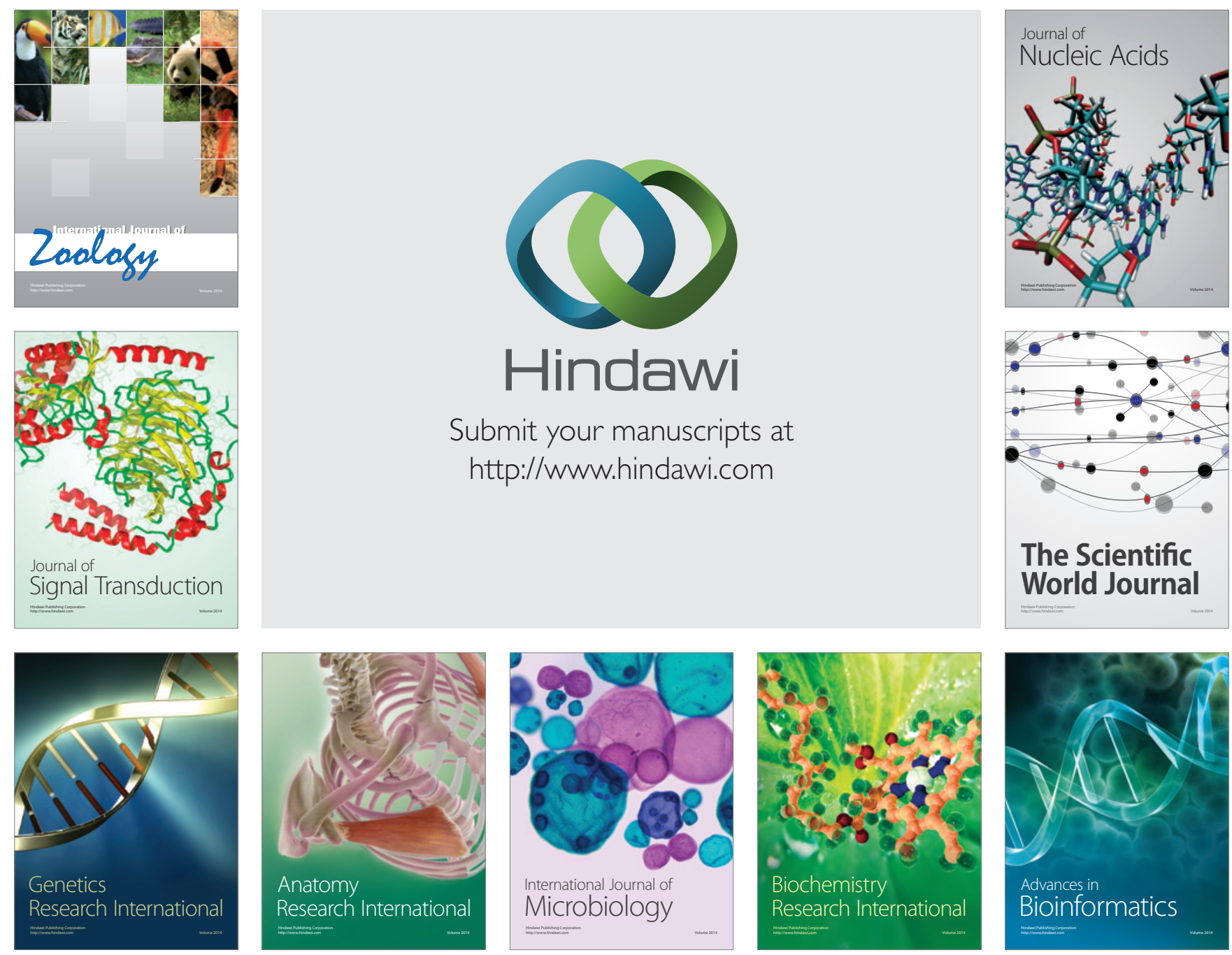

The Scientific World Journal
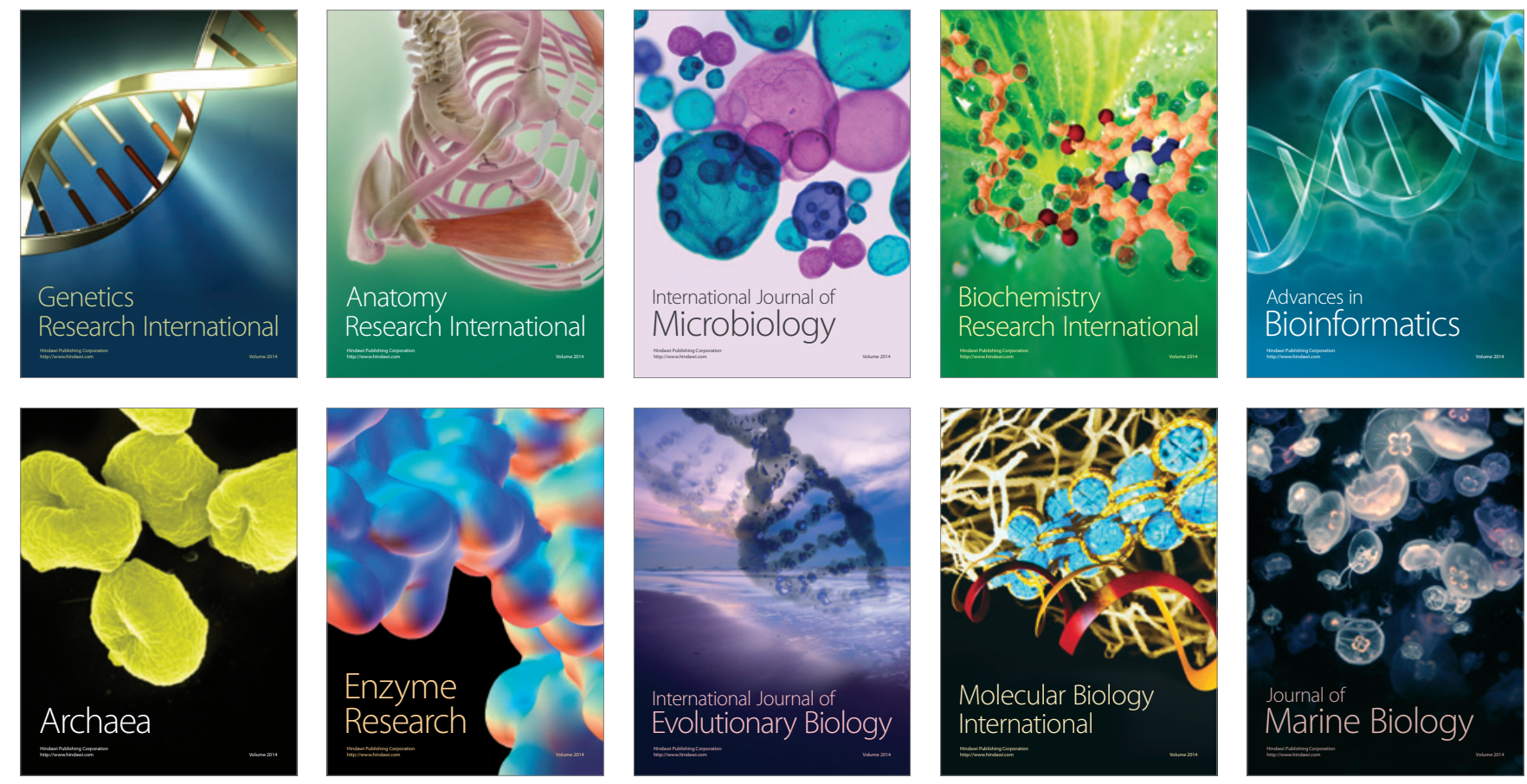